\title{
Measuring Quality of Citizens' Participation in Local Development
}

\author{
Andi Ahmad Yani \\ Department of Administrative Science \\ Hasanuddin University \\ Makassar, Indonesia \\ aayani@unhas.ac.id \\ Andi Rahmat Hidayat \\ Department of Political Science \\ University of West Sulawesi \\ Majene, Indonesia \\ avatar.rahmat@gmail.com
}

\author{
Amril Hans \\ Department of Administrative Science \\ Hasanuddin University \\ Makassar, Indonesia \\ amrilhans@gmail.com \\ Andi Yudha Yunus \\ Department of Communication Science \\ University of Perjuangan Republik Indonesia \\ Makassar, Indonesia \\ y_yunus2002@yahoo.com
}

\author{
Salma Tadjang \\ Institute for Public Policy \\ Study (LSKP) \\ Makassar, Indonesia \\ salmawani@yahoo.com \\ Abd Naris Agam \\ Institute for Public Policy \\ Study (LSKP) \\ Makassar, Indonesia \\ narissarbat86@gmail.com
}

\begin{abstract}
The main purpose of this study is to present the quality of citizens participation in the process of local development in Kutai Kartanegara Regency. It is argued that four main aspects of participation namely access, awareness, control and benefit are the key in determining the quality of participation. By examining these four aspects, it is found that the quality of citizens participation in Kutai Kartanegara refers to placation leader, where the quality of participation at this level is just merely formalism. In other words, the government sets opportunity for dialogue with people to propose program in development process, but it just aims to gain support from the community without any burden to realize the proposed program.
\end{abstract}

Keywords: citizen participation; local development; local governance

\section{INTRODUCTION}

Since the fall of Suharto's regime (new order), there has been a major change in the system of governing bureaucracy and politics. Indonesia, in this sense, has been transformed from a very centralized country to be one of the most decentralized in relatively short time [1]. This can be seen in the implementation of decentralization system, where the role of local government in development process has become key element, as power and authority have been delegated from central to local. In other words, this major change came up as reformation era began, and it was driven by neo-institutional perspective in reorganizing administration and authority to accelerate development at regional level [2]. Decentralization is seen as "middle way" for the devolution of economic and political authority and is aimed at generating creative and contextual policy initiatives for the region and promoting public participation [3].

Current regional development strategies require participation from the community, based on the assumption that society should not only be seen as object of government policy, but it has to be considered as key players. Therefore, society or stakeholder group's participation is essential component of sustainable development and decision making [4]. This system is very different from the previous under new Corresponding author: Andi Ahmad Yani order, in which the central government constantly controls the various resources, economy and politics in all regions. At that time, many of the people (especially outside Java) did not really feel the New Order development period, except for corruption, collusion and nepotism derived from the center [5].

Given the context of Indonesian political system and administration that had experienced a tremendous control by the center (under authoritarian regime of Suharto), the study of citizens participation at regional level is therefore an important empirical endeavor to see how far decentralization has been translated by local government in order to empower local participation in development activities.

There is a concept, in development discourse, that has gained popularity and has been considered as an umbrella term for new genre of development intervention, called participation [6]. With regard to democratic values, participation is also defined as a fundamental ingredient for political and social process and bureaucracy to achieve its goals. Therefore, it is argued that citizen participation is a viable way in the context of local development, and it is also a categorical term for citizens power, enabling them to deliberately engage in political and economic process where they are excluded before [7].

However, there is still an ongoing criticism whether channels of participation in development process is truly a spirit of the process or just merely manipulation by which government tries to do in development or even collaborative process [7], [8]. Without redistribution of power, participation could be an empty and frustrating process for those who powerless, particularly for ordinary citizens, and it seems that development process via participation in this sense, only maintain the status quo.

There are eight typologies of participation that can help us analyze this confusion and understand citizens power in determining the final result of development process [7]. The very bottom level is manipulation or therapy which describes non-participation process, because the main purpose of this is just to enable powerholders to educate the participants, instead 
of allowing them to determine planning and implementation process. The second higher level of participation is informing and consultation called Tokenism. This process allows participants to hear and have voice, but they have no power to ensure that their aspiration is going to be taken by the powerful/authority into account. Highest level of tokenism is called placation, giving rules for citizens to advice. The third, highest level of participation is citizen power, with increasing degrees of decision-making power held by citizens. This level is divided into three categories as this power held by citizens progressed up (partnership, delegated power, and citizen control). In partnership, citizens are able to negotiate and engage in trade-offs with traditional power holders (government). For delegated power and citizen control, people have majority of power in decision-making process. In other words, citizens have full managerial power to control output of formulation or decision-making process, or even in implementation.

So far, several studies were conducted to explore various factors that affect the quality of citizens participation [9], [10], [11], [12]. Each of these studies focused on one or some but not all aspects of these components (access, awareness, control and benefits). The position of this paper then examined these four key components that affect the quality of community participation in development process.

Access means channeling citizen to involve in development process (policy formulation, implementation and evaluation and monitoring). Citizens will participate if the government provides access in each process with certain roles. The greater the access space is opened, the higher the quality of community participation in regional development.

Awareness refers to citizens' understanding of their position as part of a state system within the framework of democracy. If citizens' understanding is low, it assumes that people tend to be apathetic and will not involve in process of planning and implementation. Conversely, if citizens' awareness is high, then of course the community will be more active to participate. The higher the awareness of the citizens, the more qualified the participation will be.

Control is associated with the position of citizens in controlling political power as the foundation of the democratic system. If the position of citizens in controlling public decisions is weak then citizens will tend to limit themselves to engage in the development process. But if the citizen's control in the decision-making process is strong, then the community will always actively play its role to control the power to ensure that policies are carried out in accordance with common interests.

Benefit component in community participation relates to community appraisal in terms of their role in development process. If people feel the impact of development, they will be more active to be involved in the development process. In contrast, if people do not feel the benefits of development, then they tend to be more apathetic.

This study uses a ladder participation model introduced by Arnstein to analyze how large the influence of these four components toward citizens' participation in development process in Kutai Kartanegara Regency.

\section{RESEARCH METHOD}

Approach used in this study is mixed method, with combination of quantitative and qualitative data. Quantitative data was taken through survey and qualitative data was gathered through focus group discussion and depth interview.

This research was conducted in nine sub-districts as sample of the total of 18 sub-districts in Kutai Kartanegara Regency. Those sub-districts selected based on geographic consideration that was interpreted to be representing all areas of Kutai Kartanegara. The following is the areas as mentioned:

Table 1: Selected sub-districts and Number of residences (2015)

\begin{tabular}{|c|c|}
\hline Sub-districts & Number of residents \\
\hline Tabang & 10,349 \\
\hline Muara Kaman & 36,266 \\
\hline Muara Badak & 45,954 \\
\hline Samboja & 63,467 \\
\hline Tenggarong & 114,306 \\
\hline Mara Muntai & 18,336 \\
\hline Anggana & 40,702 \\
\hline Kota Bangun & 33,296 \\
\hline Tenggarong Seberang & 71,467 \\
\hline
\end{tabular}

Source: Center Bureau of Statistic, 2016

To determine the number of samples, this study used the population of Kutai Kartanegara Regency in 2015, accounting for 717,789 people [13]. Based on this population, samples were taken by using a multi-stage random sampling method, with cross sectional formula. For the confidence level of $95 \%$ and margin error 0,03 , the ideal number of samples is 420 people.

Descriptive method was used to analyze qualitative data by grouping a variety of information that has been collected based on the relevance of each variable. Analytical technique on quantitative approach by survey will be processed by using descriptive statistical data analysis technique to measure frequency in cross table analysis. Average analysis method then was applied to see respondents' answers on each variable participation, by the following formula:

$$
\overline{\mathbf{X}}=\frac{\sum(\mathbf{F . X})}{\mathbf{N}}
$$

Note: $\mathrm{X} \quad$ : Average

$\sum$ (F.X): Score for categorized answers

$\mathrm{N} \quad$ : The number of respondents

The above formula serves as the basis of analysis to calculate the value of quality of citizens participation in local development. The result then could be converted and confirmed into level of participation quality (ladder participation). Conversion per-variable values is presented in table 2 below: 
Table 2: Ladder Participation (Arnstein)

\begin{tabular}{|c|c|}
\hline Scores & Ladder Participation \\
\hline $28.57-32.00$ & Citizen Control \\
\hline $25.06-28.56$ & Delegated Power \\
\hline $21.55-25.05$ & Partnership \\
\hline $18.04-21.54$ & Placation \\
\hline $14.53-18.03$ & Consultation \\
\hline $11.02-14.52$ & Informing \\
\hline $07.51-11.01$ & Therapy \\
\hline $04.00-07.50$ & Manipulation \\
\hline
\end{tabular}

\section{RESULT AND DISCUSSION}

One of the basic principles of decentralization is to give local government authority in to manage their region generally through public management (services) and public policy. This delegation of authority is expected to generate effective regional development by engaging the broadest possible participation of citizens. In other words, collaboration between government and society is a fundamental element to the success of regional development.

As mentioned earlier, four fundamental aspects of participation, that we considered valuable, were selected to understand citizens' participation in Kutai Kartanegara Regency. Access is fundamental because community participation can only be undertaken if people have access to active participation, and the government opens access to the widest possible opportunity for all citizens to participate. Although access is widely available but the community has no awareness to engage, the quality of community participation is still difficult to meet. Therefore, public awareness toward the importance of participation in regional development process becomes one of the main components in the quality of participation. In addition, communities are also expected to have controls to ensure that their engagement efforts can be well appreciated by all interest groups involved. Finally, the benefit aspect is also one of the main factors affecting the community to be involved in regional development.

Our findings will be further explained below, given to the four aspects of participation in regional development process in Kutai Kartanegara.

\section{A. Access}

Citizens in Kutai Kartanegara have the opportunity to engage in decision making with the highest value on community recognition, obtaining invitations to engage (2.96) in development process, especially in formulation stage. In addition, the public also recognizes the opportunity for dialogue and negotiation (2.95) which is fundamental to the decision-making process. However, the values at the level of decision-making and determining have been relatively low, accounting for 2.80 and 2.66 respectively.

Thus, the accumulated conversion value of the level of community participation quality in the access component is 21.42 which refers to placation level, meaning that access available is just simply to channel the aspirations of the community where their aspirations are not the main concern to be considered in regional development.

Table 3: Access aspect

\begin{tabular}{|l|l|}
\hline \multicolumn{1}{|c|}{ Indicator } & Score \\
\hline $\begin{array}{l}\text { There was opportunity to engage but merely } \\
\text { formalism }\end{array}$ & 2.09 \\
\hline Receive invitation to engage & 2.96 \\
\hline Being informed about opportunity to engage & 2.44 \\
\hline $\begin{array}{l}\text { Had opportunity to speak but their advice or } \\
\text { aspiration were not always heard }\end{array}$ & 2.79 \\
\hline $\begin{array}{l}\text { Had opportunity to give advice but their aspiration } \\
\text { was not always implemented }\end{array}$ & 2.73 \\
\hline Had opportunity to talk and negotiate & 2.95 \\
\hline Had opportunity to have role in decision-making & 2.80 \\
\hline Had opportunity to determine/decide & 2.66 \\
\hline \multicolumn{1}{|c|}{ Total value } & $\mathbf{2 1 . 4 2}$ \\
\hline
\end{tabular}

Citizens access to regional development process in Kutai Kartanegar refers to placation level.

\section{B. Awareness}

Awareness is important thing that moves individuals to engage in development activities. As shown in the table below, indicators about public awareness over their basic rights to be involved and to determine decision and also provide advice on government activities are the highest value, with 2.93 respectively. Similarly, the value of community awareness indicators to be involved and play an active role in community and government activities accounts for 2.89.

The total value of the awareness component is 19.91 which means that public awareness for participation refers to placation level. In other words, the quality of participation in Kutai Kartanegara is still at a level to dampen the disappointment of citizens where the public's awareness is very high on their basic rights to engage and determine programs in development process.

Table 4: Awareness aspect

\begin{tabular}{|l|c|}
\hline \multicolumn{1}{|c|}{ Indicator } & Score \\
\hline $\begin{array}{l}\text { Do not care with social and governmental } \\
\text { activities }\end{array}$ & 1.85 \\
\hline $\begin{array}{l}\text { Social and government activities did not fit with } \\
\text { my interest }\end{array}$ & 2.16 \\
\hline My involvement depended on my interest & 2.07 \\
\hline $\begin{array}{l}\text { Merely involved in social and government } \\
\text { activities }\end{array}$ & 2.26 \\
\hline $\begin{array}{l}\text { Involved in giving advice in social and } \\
\text { government activities }\end{array}$ & 2.93 \\
\hline $\begin{array}{l}\text { Actively involved in social and government } \\
\text { activities }\end{array}$ & 2.89 \\
\hline $\begin{array}{l}\text { Actively involved and participated in social ad } \\
\text { government activities }\end{array}$ & 2.83 \\
\hline $\begin{array}{l}\text { Knowing their basic rights as citizen to involve } \\
\text { and determine }\end{array}$ & 2.94 \\
\hline \multicolumn{2}{|c|}{ Total value } \\
\hline
\end{tabular}




\section{Control}

The next aspect of participation is control. This relates to the certainty of the position of decision-making power that the people has which then influences their participation rate. The table below shows the weak control of citizens over the programs they proposed, even though score of the government to open dialogue in terms of the determination of development activities has a very high value, at 3.07. In addition, indicator indicating that the government only provides information to the community about development activities is also relatively high at 2.92 .

The total value of Control component is 21.08 , meaning that public participation in controlling public decision is still at placation level. This condition then affects the quality of citizens participation because of weak position of their control in the process of policy making.

Table 5: Control aspect

\begin{tabular}{|l|c|}
\hline \multicolumn{1}{|c|}{ Indicator } & Score \\
\hline $\begin{array}{l}\text { Government determined all developmental } \\
\text { activities }\end{array}$ & 2.36 \\
\hline $\begin{array}{l}\text { People were just involved in determining } \\
\text { developmental activities }\end{array}$ & 2.31 \\
\hline $\begin{array}{l}\text { Government only informed to people about } \\
\text { developmental activities }\end{array}$ & 2.92 \\
\hline $\begin{array}{l}\text { Only involved few people in determining } \\
\text { developmental activities }\end{array}$ & 2.29 \\
\hline $\begin{array}{l}\text { Involved people but not in determining } \\
\text { developmental activities }\end{array}$ & 2.67 \\
\hline $\begin{array}{l}\text { Government opened up a room for dialogue to } \\
\text { determine developmental activities }\end{array}$ & 2.07 \\
\hline $\begin{array}{l}\text { Government gave a room for people to determine } \\
\text { developmental activities }\end{array}$ & 2.85 \\
\hline $\begin{array}{l}\text { All developmental activities determined by } \\
\text { people }\end{array}$ & $\mathbf{2 1 . 0 8}$ \\
\hline
\end{tabular}

\section{Benefits}

The last component of participation in this research is benefit. People are likely to participate in development activities if they feel it will bring a positive impact (benefits) to them. In the following table, it could be seen that the people received the benefit of the development programs conducted by local government of Kutai Kartanegara, and this category received the highest score at 3.02. However, programs implemented by the government has not yet fulfilled the public expectations. This can be confirmed in indicators that state development benefits have met some of citizens' expectations (2.75), and people know the information about benefits from development programs, but it does not bring direct impact to their life (2.70).

Thus, the overall value of the benefit components is 20.65 , which means that the citizens participation rate in Kutai Kartanegara refers to placation level. This data illustrates that the people only consider the benefits they receive from development activities as just to muffle their anger. This is proved by the people's perception who tend to be less satisfied with the benefits they receive because it has not been in accordance with their expectations.

Table 6: Benefit aspect

\begin{tabular}{|l|c|}
\hline \multicolumn{1}{|c|}{ Indicator } & Score \\
\hline $\begin{array}{l}\text { People did not feel benefits of development } \\
\text { activities }\end{array}$ & 2.17 \\
\hline $\begin{array}{l}\text { Only few or certain groups of people got } \\
\text { advantages from development activities }\end{array}$ & 2.09 \\
\hline $\begin{array}{l}\text { People know the benefits of development } \\
\text { activities from information provided by the } \\
\text { government but do not feel the benefits directly }\end{array}$ & 2.70 \\
\hline $\begin{array}{l}\text { There are benefits but these have not solved the } \\
\text { problem }\end{array}$ & 2.68 \\
\hline $\begin{array}{l}\text { There are benefits but these have not met the } \\
\text { expectations of the people }\end{array}$ & 3.02 \\
\hline $\begin{array}{l}\text { The benefits of development already meet some } \\
\text { of the expectations of the people }\end{array}$ & 2.75 \\
\hline $\begin{array}{l}\text { Benefits of development activities meet the } \\
\text { expectations of the people }\end{array}$ & 2.65 \\
\hline $\begin{array}{l}\text { Benefits of development activities meet the } \\
\text { expectations of the people, and it is managed by } \\
\text { the community in a sustainable manner }\end{array}$ & 2.59 \\
\hline \multicolumn{2}{|c|}{ Total value } \\
\hline
\end{tabular}

Table 7: Quality of citizen participation

\begin{tabular}{|c|c|c|c|}
\hline Variable & Score & Weight & Value \\
\hline Access & 21.42 & 16 & 342.7 \\
\hline Awareness & 19.91 & 16 & 318.6 \\
\hline Control & 21.08 & 16 & 337.3 \\
\hline Benefits & 20.65 & 16 & 330.4 \\
\hline Total & 83.06 & & 1329.0 \\
\hline
\end{tabular}

After examining four selected components to measure citizen participation in local development in Kutai Kartanegara Regency, it can be said that the level of citizens participation in this regency implies to tokenism level, where people is given space to argue and propose the program. However, the final decisions remain to be the domain of the government to determine, and it often seems not to present public's preferences.

Moreover, during the interview with key informants, there were similar problems in development process, mainly in the stage of policy determination, that happened in all 9 subdistricts. The main reason of these problems is due to the lack of local government to manage three channels of aspirations (participative, aristocrat and politicians' aspirations) that affect the determination of final programs in district government. Participative planning in development process refers to collaborative effort in which programs are formulated on the basis of people's preferences, and it is usually done through community consultation on development (musrenbang). However, development plan owned by local government work units (SKPD) in Kutai Kartanegara is often contradicted and not in accordance with the programs generated through 
community consultation. In addition, aspiration by members of local legislative assembly (DPRD) often defeats programs from participative planning. Both aristocrat style of development plan and politicians' aspiration are much stronger than participative planning in shaping development programs in Kuta Kartanegara.

This condition then confirms the weak position of citizens' control over the determination of development programs which it turn affects their participation rate in the process of development. The main advantage of decentralizing decisionmaking process in the spirit of decentralization stems from the notion that lower-level decision makers seem to have better understanding and access to information about problems they face [14], [15].

Understanding mechanism of participation that will be utilized in development process is critical to improving the management and success of sustainable development [16]. It can therefore be stated that participative planning should be the primary instrument in generating and determining development programs in regional level.

\section{CONCLUSION}

This study of citizens participation focuses on four main components of participation namely, access, awareness, control and benefits. The four components have their own levels according to the ladder of the quality of Arnstein's participation (1969). The results of citizens participation of Kutai Kartanegara showed that the quality of participation in these four components is all at the level of placation, where the highest score can be seen in the access component and the lowest in the awareness component. In general, the capacity for participation shows that the level is still at the position of Tokenism. In similar vein, citizens participation is just an emphasize of formal procedure, where government provides space for dialogue with the community in proposing the program, but its function is simply just to get support from them without any burden to realize the proposed program by the community. As a result, democratic and interactive processes for local participation are determining factor in achieving development goals [17].

\section{REFERENCES}

[1] E. Aspinall and Fealy, Introduction: decentralization, democratization and the rise of the local', in E. Aspinall and G. Fealy (eds) Local Power and Politics in Indonesia: Decentralisation and Democratisation, Institute of Southeast Asian, 2003.

[2] V.R.Hadiz. Decentralization and Democracy in Indonesia: A Critique of Neo-Institutionalist Perspectives, Development and Change, 35(4), 697-718, 2004.

[3] M.R.Rasyid, Regional Autonomy and Local Politics in Indonesia.in E, Aspinall and G. Fealy, Local Power and Local Politics in Indonesia: Decentralization and Democratization. Singapura: ISEAS, 2004.

[4] J.Carew-Reid, J, Prescott-Allen, R, Bass, S and Dalal-Clayton, DB. Strategies for National Sustainable Development: A Handbook for their Planning and Implementation. IIED and IUCN, 1994.

[5] E. Maibeth, S. Priyambudi, F. Carole, Regionalism in Post-Suharto Indonesia, RoutledgeCurzon, London and New York, 2005.

[6] P.Oakley. The concept of participation in development. Landscape Urban Planning, 20, 115 122, 1991.
[7] S.R.Arnstein, A Ladder of Citizen Participation, Journal of the American Institute of Planners, 35(4), 216-224, 1969.

[8] G.A.Ansell C Collaborative Governance in Theory and Practice, Journal of Public Administration Research and Theory. 18(4): 543-571, 2007.

[9] A.M.Evans, and A.Campos Open Government Initiatives: Challenges of Citizen Participation, Journal of Policy Analysis and Management, 32 (1), 172-185, 2012.

[10] F.Archon, "Putting the Public Back into Governance: The Challenges of Citizen Participation and Its Future", Public Administration Review, Vol. 75, Iss. 4, pp. 513-522, 2015.

[11] B.John M., K. S. Quick, C.S. Slotterback, B. C. Crosby, "Designing Public Participation Processes", Public Administration Review, Vol. 73, Iss. 1, pp. 23-34, 2012.

[12] N. Crosby, J. M. Kelly and P. Schaefer, "Citizens Panels: A New Approach to Citizen Participation", Public Administration Review, Vol. 46, No. 2, pp. 170-178, 1986

[13] Central Bureau of Statistics of Kutai Kartanegara, 2016.

[14] Fiszbein, A. (1997). The emergence of local capacity: Lessons from Colombia. World Development, 25(7), 1029-1043.

[15] J. C. Ribot. Democratic decentralization of natural resources: Institutionalizing popular participation. Washington, DC: World Resources Institute, 2002.

[16] C.V. Hawkins, and X.Wang. Sustainable Development Governance: Citizen Participation and Support Network in Local Sustainability Initiatives, Public Works Management and Policy, 17(1), 7-29, 2012.

[17] G.F. Maria, "Importance of local participation in achieving equity in benefit-sharing mechanisms for REDD+: a case study from the Juma Sustainable Development Reserve" International Journal of the Commons, Vol. 7, no. 2, pp. 473-497, 2013. 